\title{
Diagnóstico de endoftalmitis por método microbiológico convencional y molecular en pacientes de centros oftalmológicos de Paraguay
}

\author{
Norma Fariña, Margarita Samudio, Carolina Duré, Yolanda López, Sonia Abente, \\ Rosa Guillén, Julio Barrios \\ Universidad Nacional de Asunción. Instituto de Investigaciones en Ciencias de la Salud. San Lorenzo, Paraguay \\ Cómo referenciar este artículo/ \\ How to reference this article: \\ Fariña N, Samudio M, Duré C, López $Y$, Abente S, \\ Guillén R, Barrios J. Diagnóstico de endoftalmitis por \\ método microbiológico convencional y molecular en \\ pacientes de Centros Oftalmológicos de Paraguay. \\ Mem. Inst. Investig. Cienc. Salud. 2019; 17(2): 77-85
}

\section{R E S U M E N}

La endoftalmitis infecciosa es una condición intraocular grave, aunque poco frecuente, que puede llevar a la pérdida de la visión. El diagnóstico etiológico precoz y el tratamiento adecuado llevan a una mejor evolución. Las técnicas microbiológicas convencionales tienen baja sensibilidad en el diagnóstico de la endoftalmitis infecciosa, en cambio la reacción en cadena de la polimerasa (PCR) es un método de mayor sensibilidad que está siendo utilizado ampliamente. El objetivo fue determinar por cultivo y PCR la etiología de la endoftalmitis infecciosa en pacientes que consultaron en centros oftalmológicos de Paraguay. Se estudiaron muestras de humor vítreo obtenidas por punción de 51 pacientes con endoftalmitis. La muestra se dividió en dos alícuotas; una para el estudio microbiológico convencional y la otra para la PCR anidada. Esta última utiliza un par de cebadores basado en secuencias conservadas del gen $16 \mathrm{~S}$ ribosomal y cebadores específicos para bacterias gram positivas. Se estandarizó la PCR logrando una sensibilidad de detección de $3.10^{-5}$ $\mathrm{ng} / \mu \mathrm{l}$ para $S$. aureus, $2,5.10^{-3} \mathrm{ng} / \mu \mathrm{l}$ para $S$. pneumoniae y $6.10^{-7} \mathrm{ng} / \mu \mathrm{l}$ para E. coli. De las 51 muestras, $12(23,5 \%)$ fueron positivas por métodos microbiológicos convencionales y 26 $(51,0 \%)$ por la PCR anidada. Por cultivo se identificaron predominantemente bacterias grampositivas $8 / 11(73 \%)$ y un aislado de hongo filamentoso. La PCR anidada presentó muy buena sensibilidad y de gran utilidad en la identificación del origen bacteriano de la endoftalmitis, mejorando la sensibilidad del cultivo en $27,5 \%$. La discriminación bacteriana en grampositivos y gramnegativos por la PCR se correlacionó con el cultivo en el $100 \%$ de los casos.

Palabras clave: endoftalmitis bacteriana, etiología, PCR, cultivo, sensibilidad diagnóstico molecular.

\section{Diagnosis of endophthalmitis by molecular and conventional microbiological methods in patients from ophthalmologic centers of Paraguay}

\section{A B S T R A C T}

Infectious endophthalmitis is a serious intraocular condition, although it is rare, often results in vision loss. The early etiological diagnosis and appropriate treatment leads to a better outcome. Conventional microbiological techniques have low sensitivity in the diagnosis of infectious endophthalmitis, however polymerase chain reaction (PCR) is a more sensitive method which is widely used. The goal was to determine the etiology of infectious endophthalmitis by culture and PCR in patients who consulted in ophthalmologic centers in Asunción, Paraguay. Vitreous fluid samples obtained by puncture from 51 patients with endophthalmitis were studied. Samples were divided into two aliquots; one was used for the

Fecha de recepción: junio 2019. Fecha de aceptación: julio 2019

*Autor correspondiente: Margarita Samudio. Email: margarita.samudio@gmail.com 
conventional microbiological study and the other for the nested PCR. The latter uses a pair of primers based on conserved sequences of the $16 \mathrm{~S}$ gene ribosomal and specific primers for gram positive bacteria. Detection sensitivity of the nested PCR was $3.10^{-5} \mathrm{ng} / \mu \mathrm{l}$ for $S$. aureus, $2.5 .10^{-3} \mathrm{ng} / \mu \mathrm{l}$ for S. pneumoniae and $6.10^{-7} \mathrm{ng} / \mu \mathrm{l}$ for E. coli. Out of 51 samples, $12(23.5 \%)$ were positive for conventional microbiological methods and $26(51.0 \%)$ by nested-PCR. Gram-positive bacteria were predominant $8 / 11(73 \%)$ by culture and one filamentous fungus was isolated. The nested PCR presented very good sensitivity and very useful for the identification of the bacterial origin of endophthalmitis, improving culture sensitivity in $27.5 \%$. Bacterial discrimination in Gram positive and Gram negative by PCR correlated $100 \%$ with the culture.

Keywords: bacterial endophthalmitis, etiology, PCR, culture, sensitivity, molecular diagnosis.

\section{INTRODUCCIÓN}

La endoftalmitis infecciosa es una rara pero severa inflamación de los tejidos intraoculares, que resulta de la introducción de microorganismos en el segmento posterior del ojo, requiere de atención médica inmediata, e incluso con la intervención terapéutica y quirúrgica, puede conducir a la pérdida parcial o completa de la visión ${ }^{(1)}$. Según el mecanismo de adquisición, la endoftalmitis se clasifica en: postoperatoria (aguda o de aparición tardía), postraumática, endógena y otras en las que se incluye la secundaria a la queratitis $^{(2)}$. La endoftalmitis postoperatoria es la presentación más común y se asocia frecuentemente con la cirugía de cataratas. Los patógenos causales generalmente son originarios de la microbiota conjuntival normal y los párpados, siendo las bacterias grampositivas más frecuentes $(94,2 \%)$ que las gram-negativas $(6,5 \%)$ en los casos agudos de endoftalmitis postoperatorias, principalmente los estafilococos, estreptococos y enterococos ${ }^{(3)}$. La endoftalmitis postraumática es también causada principalmente por la flora ocular normal, siendo los estafilococos y $B$. cereus los más comunes ${ }^{(4,5)}$. La endoftalmitis endógena es menos frecuente, 2 a $8 \%$ de los casos de endoftalmitis y cualquier patógeno que causa bacteriemia o sepsis puede causar endoftalmitis al tener acceso al segmento posterior del ojo, especialmente en huéspedes inmunocomprometidos 0 adictos a drogas intravenosas ${ }^{(6)}$.

El diagnóstico microbiológico de la endoftalmitis se realiza de forma rutinaria mediante coloración de Gram y cultivo de muestras tomadas del humor vítreo y humor acuoso. Sin embargo, las técnicas microbiológicas convencionales son a menudo insuficientes para confirmar los casos clínicos sospechosos de endoftalmitis debidos a la baja sensibilidad y al tiempo que demora. La falta o retraso de una confirmación por un laboratorio microbiológico puede conducir a la mala utilización de la terapia farmacológica oftalmológica con toxicidad ocular potencial, así como al uso empírico de antibióticos de amplio espectro durante varios días, retrasándose el inicio del tratamiento antibiótico correcto hasta la identificación definitiva del microorganismo causal ${ }^{(7-9)}$.

La aplicación de las técnicas de biología molecular en microbiología clínica, tales como la reacción en cadena de la polimerasa (PCR), hace posible la detección de microorganismos difíciles de detectar por métodos microbiológicos tradicionales y reducir el tiempo de confirmación por el laboratorio, esencial en la caracterización de los microorganismos implicados en las infecciones graves y de rápido desarrollo ${ }^{(10)}$.

Varios autores mostraron cómo la utilización de la PCR en la detección directa de patógenos a partir de muestras de humor acuoso y vítreo podría afectar efectivamente el diagnóstico de endoftalmitis bacteriana ${ }^{(11-14)}$. Carroll et al. ${ }^{(15)}$ estandarizaron una reacción de PCR anidada para diferenciar microorganismos Gram positivos de Gram negativos. La reacción consistió en un par de cebadores universales en la primera reacción, y una combinación de cebadores universales y gram-específico en la segunda ronda de la reacción. Numerosas otras técnicas han sido probadas para el diagnóstico de las endoftalmitis con resultados variables, la PCR convencional y a tiempo real, así como las reacciones post-PCR tales como RFLP, hibridación de la sonda de ADN y la secuenciación del ADN se han utilizado con éxito para la elucidación de diagnóstico de casos clínicamente sospechosos de endoftalmitis bacterianas, por lo que la aplicación de técnicas moleculares es prometedora para utilizar en el diagnóstico de rutina de las endoftalmitis ${ }^{(16-18)}$.

Ante la necesidad de contar con un método eficaz para el diagnóstico etiológico de las endoftalmitis infecciosas en nuestro país, se realizó este estudio para evaluar el método 
microbiológico convencional que consta de coloración de Gram, cultivo e identificación y una técnica de PCR anidada basada en la desarrollada por Carroll et. ${ }^{(15)}$ en pacientes provenientes de centros oftalmológicos de Paraguay, a fin de aumentar sustancialmente la confirmación de los casos sospechosos de endoftalmitis infecciosa, mejorar el tratamiento correcto y oportuno y por ende la evolución del paciente.

\section{METODOLOGÍA}

Se realizó un estudio observacional descriptivo de corte transverso en pacientes con sospecha de endoftalmitis que consultaron entre enero de 2014 a julio de 2018 en tres centros oftalmológicos de Asunción: Cátedra de Oftalmología del Hospital de Clínicas, Fundación Visión y Banco de Ojos.

\section{Toma de muestra}

La muestra de humor vítreo fue recolectada de los pacientes con sospecha de endoftalmitis en condiciones estériles, por los médicos oftalmólogos responsables de cada centro, con aguja estéril $27-$ gauge $(0.33-\mathrm{mm}$ de diámetro). Posterior a una inyección subconjuntival de anestesia, una abertura vítrea fue realizada y la aguja introducida a través de la pars plana $3 \mathrm{~mm}$ detrás del limbo en ojos afaquicos y $4 \mathrm{~mm}$ detrás del limbo en ojos faquicos. Fue aspirado un volumen de 200 a $500 \mu \mathrm{l}$ y enviado dentro de las dos horas al laboratorio de Microbiología del Instituto de Investigaciones en Ciencias de la Salud.

\section{Estudio microbiológico}

Una vez recibida la muestra fue alicuotada y una parte transferida a un microtubo estéril $\left(50\right.$ a $100 \mu \mathrm{l}$ ) y almacenada a $-20^{\circ} \mathrm{C}$ para ser utilizada posteriormente para el diagnóstico etiológico por PCR. La parte restante de la muestra fue inoculada en agar sangre de carnero al 5\%, agar chocolate, caldo tioglicolato, agar sabouraud y una gota depositada en lámina estéril para coloración de Gram. La placa de agar sangre y el caldo tioglicolato se incubaron en condiciones aeróbicas a $35^{\circ} \mathrm{C}$, el agar chocolate en anaerobiosis a $35^{\circ} \mathrm{C}$ y el agar sabouraud a $28^{\circ} \mathrm{C}$. Los cultivos fueron incubados por 15 días.

\section{Identificación de microorganismos y pruebas de sensibilidad}

La identificación de especies fue realizada por los métodos microbiológicos convencionales, mediante pruebas bioquímicas (catalasa, manitol, DNAsa, urea, bilis esculina, prueba de CAMP, oxidasa, TSI, citrato, decarboxilación de la lisina y ornitina, indol, rojo de metilo, Voges-Proskauer) y pruebas de aglutinación ${ }^{(19)}$. La identificación de estafilococos coagulasa-negativo realizado según el diagrama de identificación de Paulis et al., con algunas modificaciones ${ }^{(20)}$ y en los casos en que no fue posible la identificación de algún microorganismo por los métodos convencionales, se utilizó el microsistema comercial API. Además se realizó la prueba de sensibilidad por el método de difusión con discos según Kirby Bauer, en placas de Müeller Hinton a $35^{\circ} \mathrm{C}$ e interpretó de acuerdo a las normas del CLSI (Clinical Laboratory Standard Institute) ${ }^{(21)}$. Se utilizaron cepas de referencia Staphylococcus aureus ATCC 25923, Enterococcus faecalis ATCC 29212, Pseudomonas aeruginosa ATCC 27853 y Escherichia coli ATCC 25922, para controlar la calidad de las pruebas de identificación y del antibiograma.

A medida se obtenían los resultados microbiológicos, coloración de Gram, identificación y prueba de sensibilidad se informaron al médico tratante.

Obtención y cuantificación de ADN de cepas de referencia: Las cepas de referencia utilizadas para la estandarización fueron Staphylococcus aureus ATCC 25923, Streptococcus pneumoniae ATCC 49619 y Escherichia coli ATCC 25922. Las cuales se inocularon en agar sangre por 24 a 48 horas para realizar la extracción de ADN, la cual se llevó a cabo con un kit comercial Wizard $\AA$ Genomic DNA (PROMEGA, Madison, WI, USA) a partir de las colonias frescas. Posteriormente se realizaron diluciones seriadas del ADN extraído para ensayar la sensibilidad del método. El ADN fue cuantificado por Nanodrop.

Extracción de ADN de las muestras de Humor Vítreo: Se utilizó un volumen de 50 uL de humor vítreo para la extracción de ADN con el kit comercial Wizard $®$ Genomic DNA (PROMEGA, Madison, WI, USA) siguiendo las indicaciones del fabricante. El ADN fue conservado a $-20^{\circ} \mathrm{C}$ hasta la realización de la PCR.

PCR anidada de las muestras de humor vítreo: Una vez descongeladas las muestras conservadas a $-20^{\circ} \mathrm{C}$, se utilizaron alícuotas de $2 \mu \mathrm{L}$ de ADN en la primera corrida de PCR. Los controles positivos utilizados fueron $10 \mathrm{ng}$ de ADN de cepas ATCC E. coli y S. aureus. Posteriormente se realizó la PCR anidada descrita por Carroll et al. (2000) ${ }^{(15)}$ con algunas 
modificaciones en las condiciones de reacción como aumento del número de ciclos en la primera ronda y de los tiempos de reacción en ambas rondas.

Primera ronda de amplificación: Se utilizó $0,5 \mu \mathrm{M}$ de cebadores $16 \mathrm{SF} / 16 \mathrm{SR}, 0,4 \mathrm{mM}$ de desoxinucleótido trifosfato (dNTP) Invitrogen (Thermo Fisher Scientific - USA), 3 mM de $\mathrm{MgCl} 2$ en un volumen final de $25 \mu \mathrm{L}$. La reacción se llevó a cabo con un ciclo de desnaturalización inicial a $94^{\circ} \mathrm{C}$ por 5 minutos, seguido de $94^{\circ} \mathrm{C}$ por $30 \mathrm{~s}, 54^{\circ} \mathrm{C}$ por $30 \mathrm{~s} \mathrm{y}$ $72^{\circ} \mathrm{C}$ por 1 min por 30 ciclos, y un ciclo de extensión final de $72^{\circ} \mathrm{C}$ por 5 min

Segunda ronda de amplificación: Se realizó una PCR multiplex a partir de $1 \mu \mathrm{L}$ del amplicón de la primera ronda con 0,5 $\mu \mathrm{M}$ de los cebadores NF/NR/P2F, $3 \mathrm{mM}$ de $\mathrm{MgCl} 2$ en un volumen final de $25 \mu \mathrm{L}$. La reacción se llevó a cabo con un ciclo de desnaturalización inicial a $94^{\circ} \mathrm{C}$ por 5 minutos, seguido de $94^{\circ} \mathrm{C}$ por $30 \mathrm{~s}, 60^{\circ} \mathrm{C}$ por $30 \mathrm{~s}$ y $72^{\circ} \mathrm{C}$ por 1 min por 30 ciclos, y un ciclo de extensión final de $72^{\circ} \mathrm{C}$ por 5 min.

Electroforesis y revelado: Como resultado de la segunda ronda de PCR se obtuvo un amplicón único de 1025 pb para bacterias Gram Negativas y dos amplicones de 1025 pb y de $355 \mathrm{pb}$ para bacterias gram Positivas, estos productos fueron visualizados por electroforesis en gel de agarosa al $2 \%$ previa tinción con SYBRß Safe DNA gel stain (Invitrogen, USA).

\title{
Gestión y análisis de los datos
}

Los datos de los cuestionarios fueron consignados en una planilla electrónica (Excel) y posteriormente analizados utilizando el paquete estadístico Epi-Info 2002.

\section{Aspectos éticos}

El protocolo de investigación fue aprobado por el Comité de Ética en Investigación del IICS-UNA. El estudio se ajustó a los principios éticos de la investigación clínica. No se trabajaron directamente con los pacientes sino con las muestras de los mismos que fueron tomadas por los oftalmólogos como parte de la rutina de los servicios. Se mantuvo la confidencialidad de los datos, los estudios fueron gratuitos y los resultados por métodos convencionales remitidos a los médicos tratantes para el tratamiento adecuado.

\section{RESULTADOS}

Se estudiaron 51 muestras de humor vítreo de pacientes provenientes de 3 Centros Oftalmológicos de Paraguay; Hospital de Clínicas, Fundación Visión y Banco de Ojos. El rango de edad de los pacientes fue de 24 a 77 años, predominaron los pacientes del sexo masculino, en $72,5 \%(37 / 51)$.

El origen de las endoftalmitis solamente pudo ser establecido en 31 pacientes $(60 \%)$, entre los cuales predominó el antecedente de trauma con diversos objetos como cuchillos, piedras, alambres, clavos, madera etc., en 15 pacientes $(48 \%)$, seguido de aquellos con antecedente de cirugía en 8 pacientes $(26 \%)$, en tercer lugar las presumiblemente endógenas $5(16 \%)$ y posterior a queratitis 3 casos $(10 \%)$.

Del total de muestras analizadas, 12 dieron cultivo positivo, en 11 desarrollaron bacterias y en 1 muestra desarrolló un hongo filamentoso. Entre las bacterias predominaron las Gram Positivas $73 \%(8 / 11)$. De las muestras con cultivo positivo 9 presentaron examen microscópico positivo. En la Tabla 1 se presenta los microorganismos aislados y el resultado obtenido en la Coloración de Gram.

Tabla 1: Gérmenes aislados en los cultivos y resultados en la Coloración de Gram

Coloración de Gram
Cocos Gram (+)
Cocos Gram (+)
No se observan gérmenes
Cocos Gram (+)
Cocos Gram (+) y Bacilos Gram (+)
No se observan gérmenes
No se observan gérmenes
Bacilos Gram (-)
Bacilos Gram (-)
Bacilos Gram (-)
Bacilos Gram (+)
Hifas septadas

\author{
Germen aislado \\ Streptococcus sp (Grupo viridans) \\ Streptococcus sp (Grupo viridans) \\ Enterococcus faecalis \\ Enterococcus faecalis \\ Enterococcus casseliflavus y Bacillus sp \\ Enterococcus casseliflavus \\ Staphylococcus epidermidis \\ Pseudomonas stutzeri \\ Stenotrophomonas maltophilia \\ Serratia marcescens \\ Bacillus sp \\ Aspergillus fumigatus
}

La técnica de la PCR utilizada se basó en el protocolo de Carroll et al., al cual se introdujeron modificaciones en las condiciones de reacción, como en el aumento del número 
de ciclos en la primera ronda y de los tiempos de reacción en ambas rondas según como se lo ha descripto. No se logró la amplificación con el cebador N6R específico para bacterias Gram Negativas (NF/N6R), por lo tanto se realizó la PCR con los amplicones de 355 pb para las bacterias Gram Positivas y 1025 pb para los Gram Negativos. En la Tabla 2 se muestra la sensibilidad obtenida.

Tabla 2: Sensibilidad de la detección de la PCR anidada

\begin{tabular}{ll}
\hline Cepas de referencia utilizadas & Límite de detección obtenido \\
\hline Staphylococcus aureus & hasta $3.10-5 \mathrm{ng} / \mathrm{ul}$ \\
Streptococcus pneumoniae & hasta $2,5.10-3 \mathrm{ng} / \mathrm{ul}$ \\
Escherichia coli & hasta $6.110-7 \mathrm{ng} / \mathrm{ul}$ \\
\hline
\end{tabular}

Los productos de la PCR anidada visualizados por electroforesis en gel de agarosa al $2 \%$

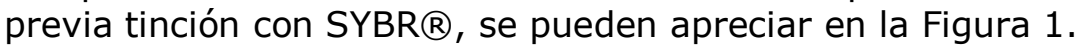

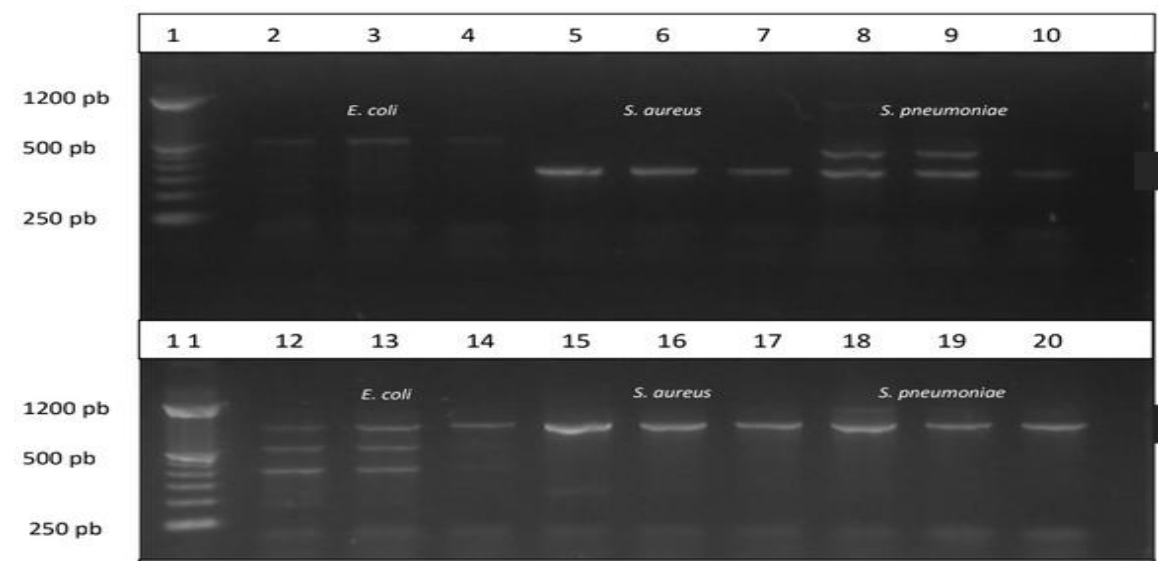

Figura 1: Productos de la PCR anidada visualizados por electroforesis en gel de agarosa al $2 \%$ previa tinción con SYBR $®$ Safe DNA gel stain. Carriles 1 al 10: Mix P2F/NR (Gram positivo-355 pb): 1Molecular marker; 2-E. coli 6,0 ng/uL ; 3-E. coli 0,6 ng/uL; 4-E. coli 0,06 ng/uL; 5-S. aureus 3,0 $\mathrm{ng} / \mathrm{uL} ; 6-\mathrm{S}$. aureus $0,3 \mathrm{ng} / \mathrm{uL} ; 7-S$. aureus $0,03 \mathrm{ng} / \mathrm{uL} ; 8-S$. pneumoniae 25,0 ng/uL; 9-S. pneumoniae 2,5 ng/uL; 10-S. pneumoniae 0,25 ng/uL. Carriles 11 al 20: Mix NF/NR (PanBacteria Universal $1025 \mathrm{pb}$ ): 1-Molecular marker; 2-E. coli 6,0 ng/uL; 3-E. coli 0,6 ng/uL; 4-E. coli 0,06 ng/uL; 5 -S. aureus 3,0 ng/uL; 6-S. aureus 0,3 ng/uL; 7-S. aureus 0,03 ng/uL; 8-S. pneumoniae 25,0 ng/uL; 9-S. pneumoniae $2,5 \mathrm{ng} / \mathrm{uL} ; 10-S$. pneumoniae $0,25 \mathrm{ng} / \mathrm{uL}$.

Por la técnica de PCR, se obtuvieron 26 muestras positivas, siendo la tasa de detección del $51 \%$. En 15 muestras que resultaron negativas por cultivo se logró la detección de ADN bacteriano. Solo una muestra positiva por cultivo, en la cual desarrolló un hongo, no pudo ser detectada por la PCR utilizada. La discriminación en Gram positivos y Gram negativos, con respecto a lo obtenido en los cultivos coincidió en un $100 \%$. También por esta técnica resultaron predominante los Gram positivos, 22/26 (84,6\%). Tabla 3

Tabla 3: Resultado comparativo por ambos métodos

\begin{tabular}{lll}
\hline $\mathbf{N}^{\circ}$ de aislados n=51 & Cultivo & PCR \\
\hline 8 & Positivo para Grampositivos & Positivo Gram (+) (355bp) \\
3 & Positivo para Gramnegativos & Positivo Gram (-) (1025bp) \\
1 & Positivo para hongo & Negativo \\
14 & Negativo & Positivo Gram (+) (355bp) \\
1 & Negativo & Positivo Gram (-) (1025bp) \\
24 & Negativo & Negativo \\
\hline
\end{tabular}

La tasa de detección por método microbiológico fue de $23,5 \%$ y por el método molecular $51,0 \%$; la sensibilidad fue $91,7 \%$ y la especificidad $61,5 \%$. Tabla 4 
Tabla 4: Comparación de los resultados por cultivo y PCR en muestras de humor vítreo.

\begin{tabular}{llccl}
\hline & \multicolumn{4}{c}{ Resultado cultivo } \\
& & Positivo & Negativo & Total \\
\hline Resultado por PCR & Positivo & $11(91,7 \%)$ & $15(38,5 \%)$ & $26(51 \%)$ \\
& Negativo & $1(8,3 \%)$ & $24(61,5 \%)$ & $25(49 \%)$ \\
Total & & $12(23,5 \%)$ & $39(76,5 \%)$ & 51 \\
\hline
\end{tabular}

S: sensibilidad E: especificidade. $S=11 / 12.100=91,7 \% . E=24 / 39.100=61,5 \%$

\section{DISCUSIÓN}

Los estudios microbiológicos convencionales para el diagnóstico de las endoftalmitis mediante cultivo de humor vítreo, humor acuoso y coloración de Gram, tienen el gran inconveniente de presentar baja sensibilidad. Según los diversos estudios, los cultivos muestran una positividad variable, entre $24 \%$ a $56 \%$ de los casos sospechosos ${ }^{(16,22-24)}$. En el presente trabajo un $23,5 \%$ de las muestras analizadas resultaron ser positivas por el método convencional. La baja sensibilidad puede deberse a diversos factores tales como: escasa cantidad de la muestra, fijación de los microorganismos en superficies sólidas (lente intraocular, fragmentos de cristalino, cápsula) y la consiguiente disminución de las células en el humor vítreo / acuoso, el uso de antibióticos antes de la toma del material clínico y la presencia de microorganismos exigentes. Además los métodos de diagnóstico por cultivo requieren la presencia de microorganismos viables para que pueda ser detectado.

La aplicación de las técnicas de biología molecular en microbiología clínica, como la reacción en cadena de la polimerasa (PCR), estableció una nueva era en la detección y caracterización de microorganismos. Varios autores mostraron que la utilización de la PCR en la detección directa de patógenos a partir de muestras de humor acuoso y vítreo podría mejorar el diagnóstico etiológico de las endoftalmitis con un rango de sensibilidad de detección de entre $57 \%$ a $100 \%{ }^{(11-14)}$. En este estudio la tasa de detección por el método molecular fue del $51 \%$, este método permitió confirmar la presencia de bacterias en 14 muestras con cultivo negativo, mejorando la tasa del diagnóstico microbiológico en un $27,5 \%$.

La detección de patógenos por PCR sólo depende de la presencia de ADN bacteriano en la muestra, independientemente si existen o no microorganismos viables, esta característica es una de las ventajas de esta técnica sobre el cultivo, por lo cual es útil, especialmente para líquidos biológicos en los cuales la microbiota normal no está presente y en aquellos casos en que se ha iniciado tratamiento antimicrobiano. Además la utilización de métodos moleculares permite el diagnóstico de microorganismos fastidiosos, de difícil detección por métodos microbiológicos tradicionales, y constituyen una excelente opción para mejorar la tasa y reducir el tiempo de diagnóstico de las endoftalmitis, especialmente en casos severos, en los cuales es crucial iniciar oportunamente la terapia apropiada, ya que de ello depende la evolución favorable del paciente ${ }^{(26)}$. En el presente estudio, con la técnica molecular utilizada el tiempo necesario para la confirmación de la etiología bacteriana fue de aproximadamente de $5 \mathrm{~h}$, mucho menor en comparación con el tiempo mínimo necesario para el diagnóstico por cultivo, que fue de $48 \mathrm{~h}$. Si bien en muchos de los casos con cultivo positivo, la microscopía fue capaz de establecer un correcto diagnóstico presuntivo inicial.

La detección del genoma eubacterial por el método de PCR ha sido desarrollado basado en las regiones conservadas de la secuencia del ADNr/ARNr $16 S$ de $E$. coli por varios grupos $^{(27,28)}$. La subunidad pequeña del rRNA contiene segmentos que se conservan a nivel de especie, género y reino. Cebadores universales elegidos del 16S rDNA tienen una gran cantidad de información de secuencia y regiones altamente conservadas del gen lo cual permite la síntesis de cebadores que amplifican una gran variedad de bacterias. La detección de ADN bacteriano utilizando cebadores universales es útil como prueba de diagnóstico rápida para determinar la etiología bacteriana, pero no proporciona información en relación con la tinción de Gram y la identificación de las especies involucradas en cada caso $^{(13)}$.

Anand et al. han intentado la discriminación entre gram positivos y negativos sometiendo los productos de PCR del gen del ARNr 16S a hibridación con sondas de ADN capaces de diferenciar los productos obtenidos en gram positivos y gram negativos. Estos autores evaluaron 57 muestras de pacientes con diagnóstico clínico de endoftalmitis, la positividad 
de los métodos microbiológicos (cultivo y microscopía) fue $56,1 \%$, la de PCR seguida de hibridación fue de $91,2 \%$, y la diferenciación entre los microorganismos gram positivos y gram negativos mostró un $100 \%$ de correlación cuando se comparó los resultados de hibridación con los de microscopía y cultivo ${ }^{(16)}$. En el presente trabajo se ha obtenido total correspondencia en la discriminación del Gram comparando el cultivo con la técnica de PCR, coincidiendo con otros autores ${ }^{(13,15,16)}$. La confirmación del Gram es sumamente útil, pues con ello se consigue orientar el tratamiento antibiótico adecuado.

Carroll et al. lograron discriminar Gram Positivos de Gram Negativos mediante una PCR anidada, empleando un par de cebadores universales en la primera ronda de la reacción y una combinación de cebadores universales y gram-específico en la segunda ronda, detectando como producto de amplificación de los patógenos gramnegativos una banda de 985 pb, y en la PCR múltiplex como producto de amplificación del genoma bacteriano y de los grampositivos, bandas de 1025 pb y 355 pb respectivamente ${ }^{(15)}$. La PCR utilizada en el presente trabajo está basada en el protocolo de estos autores, pero fue necesaria la introducción de modificaciones en las condiciones de reacción, aumento del número de ciclos en la primera ronda y de los tiempos de reacción en ambas rondas, sin embargo no se pudo lograr la amplificación con el cebador N6R específico para bacterias Gram Negativas, por lo se realizó la PCR considerando los amplicones de 355 pb para las bacterias Gram Positivas y en los casos en que solamente se detectó la banda de 1025 pb y no se consiguió amplificar gram positivos, el producto fue considerado como Gram negativo.

Numerosas otras técnicas han sido probadas para el diagnóstico de las endoftalmitis con resultados variables, tanto por PCR convencional y PCR a tiempo real, así como las reacciones post-PCR tales como análisis de restricción de productos de PCR por RFLP (polimorfismo de longitud de fragmento de restricción), hibridación con sondas de ADN o secuenciación directa de estos producto ${ }^{(16-18,29)}$.

La aplicación de la PCR en tiempo real para el diagnóstico de la endoftalmitis podría ser de gran utilidad. Esta técnica combina la amplificación y detección de una secuencia blanco de ADN utilizando sondas específicas ${ }^{(18)}$. Tiene una alta sensibilidad y elimina pasos posteriores a la PCR, obteniéndose resultados en menos tiempo. Bispo et al. aplicaron un sistema de PCR a tiempo real en muestras clínicas intraoculares para la detección y clasificación bacteriana. Obtuvieron cultivos positivos en el $47,6 \%$ y con la PCR a tiempo real en el $95,2 \%{ }^{(29)}$.

Para la identificación de la especie del agente causal por el método molecular, la secuenciación es una de las técnicas post PCR muy empleada, pero requiere de un volumen importante de producto amplificado lo que no siempre es posible debido al bajo inóculo bacteriano del fluido intraocular. La secuenciación permite conocer el género y especie pero no así la sensibilidad del agente bacteriano frente a los antibióticos. Ecker et al. han desarrollado una plataforma que utiliza espectrometría de masas de los productos de PCR ionizadas (incluidos los productos de gen del ARNr 16S), que es capaz de integrar en el mismo sistema, la identificación del microorganismo, genotipado, y la detección de la virulencia y los genes de resistencia a antibióticos ${ }^{(30)}$.

Con respecto al origen de los casos de endoftalmitis de esta serie, si bien no conocemos en su totalidad, se cuenta con los antecedentes del $60 \%$ de los pacientes entre los cuales predominaron las endoftalmitis posterior a traumas en aproximadamente el $50 \%$, seguidos de los casos postquirúrgicos,y en tercer lugar los de origen endógeno. Esto constituye una limitante del presente estudio, pues no se pudieron recabar todos los datos que podrían haber aportado mayor información.

Las bacterias gram positivas son las que se reportan como agente etiológico de las endoftalmitis más frecuentemente, tanto en las postoperatorias como postraumáticas, en las cuales los patógenos causales generalmente son originarios de la flora conjuntival normal y los párpados ${ }^{(4-6)}$. Coincidente con la literatura hemos aislado con mayor frecuencia Gram positivos entre ellos; Enterococus spp, Streptococcus sp, Staphylococcus sp y Bacillus $\mathrm{sp}$ y como ya se ha mencionado predominantemente de casos posteriores a traumas y cirugías.

Otra bacteria gram positiva reportada frecuentemente como causante de endoftalmitis, principalamente en las postquirúrgicas tardías y que no la hemos aislado en este estudio es Propionibacterium acnes, Therese et al. utilizando cebadores universales para el gen bacteriano ARNr $16 \mathrm{~S}$ y un conjunto de cebadores específicos de especie para $P$. acnes, detectaron en 9 de 58 muestras $(15,5 \%)^{(13)}$, y por cultivo obtuvieron 27 aislados $(46,5 \%)$, 
20 bacterias $(34,5 \%)$ y 7 hongos $(12 \%)$, entre las bacterias no aislaron $P$. acnes. Considerando estos hallazgos podría ser necesario el agregado de cebadores específicos para $P$. acnes. Con respecto al cultivo para hongos, obtuvimos un aislado de un hongo filamentoso, el cual como era de esperar dio negativo por PCR, pues el método utilizado no es capaz de detectar ADN fúngico. Este caso correspondió a una endoftalmitis endógena en un paciente con severo inmunocompromiso.

Por el método convencional además se pudo determinar la sensibilidad de las bacterias que desarrollaron en el cultivo frente a los antibióticos. La gran mayoría de las bacterias aisladas presentaron buena sensibilidad frente a los antibióticos (datos no mostrados), si bien algunos de los aislados como Enterococcus faecalis y Stenotrophomonas maltophilia presentan un patrón de sensibilidad muy particular característico del género y especie, en los cuales la identificación fue fundamental.

Debido a que la PCR anidada utilizada mejoró significativamente la sensibilidad y la rapidez para la detección bacteriana, se pretende implementar la utilización de la técnica para el estudio etiológico rutinario de los casos sospechosos de endoftalmitis infecciosas y así aumentar sustancialmente la confirmación bacteriana de las endoftalmitis, con lo que se logrará reducir las terribles consecuencias de esta patología por falta o demora del correcto diagnostico etiológico.

Financiación: Este estudio fue realizado dentro del marco del Proyecto14-INV-142 "Utilidad de una PCR anidada comparado con métodos microbiológicos convencionales para el diagnóstico de la endoftalmitis en pacientes provenientes de centros oftalmológicos de Paraguay" apoyado por PROCIENCIA/ CONACYT en la convocatoria 2013.

\section{REFERENCIAS BIBLIOGRÁFICAS}

1. Callegan MC, Engelbert M, Parke DW 2nd, Jett BD, Gilmore MS. Bacterial endophthalmitis: epidemiology, therapeutics, and bacterium-host interactions. Clin Microbiol Rev. 2002;15(1):111-24.

2. Kinnear FB, Kirkness CM. Advances in rapid laboratory diagnosis of infectious endophthalmitis. J Hosp Infect. 1995;(30 Suppl):253-61.

3. Taban M, Behrens A, Newcomb RL, Nobe MY, McDonnell PJ. Incidence of acute endophthalmitis following penetrating keratoplasty: a systematic review. Arch Ophthalmol. 2005;123(5):605-9.

4. Han DP, Wisniewski SR, Wilson LA, Barza $M$, Vine AK, Doft $B H$, et al. Spectrum and susceptibilities of microbiologic isolates in the Endophthalmitis Vitrectomy Study. Am J Ophthalmol. 1996; 122(1):1-17.

5. Thompson ST, Parver LM, Enger CL, Meiler WF, Liggett PE. Infectious endophthalmitis after penetrating injuries with retained intraocular foreign bodies. National Eye Trauma System. Ophthalmology. 1993; 100(10):1468-74.

6. Das T, Kunimoto DY, Sharma S, Jalali S, Majji AB, Nagaraja Rao $\mathrm{T}$, et al. Relationship between clinical presentation and visual outcome in postoperative and posttraumatic endophthalmitis in south central India. Indian J Ophthalmol. 2005; 53(1):5-16. Comment in: Indian J Ophthalmol. 2007;55(2):159; author reply 159.

7. Jackson $T L$, Eykyn SJ, Graham EM, Stanford MR. Endogenous bacterial endophthalmitis: a 17-year prospective series and review of 267 reported cases. Surv Ophthalmol. 2003;48(4):403-23.

8. Okhravi N, Adamson P, Carroll N, Dunlop A, Matheson MM, Towler HM, et al. PCRbased evidence of bacterial involvement in eyes with suspected intraocular infection. Invest Ophthalmol Vis Sci. 2000; 41(11):3474-9.

9. Van Gelder RN. Applications of the polymerase chain reaction to diagnosis of ophthalmic disease. Surv Ophthalmol. $2001 ; 46(3): 248-58$.

10. Speers DJ. Clinical applications of molecular biology for infectious diseases. Clin Biochem Rev. 2006;27(1):39-51.

11. Bagyalakshmi R, Madhavan HN, Therese $\mathrm{KL}$. Development and application of multiplex polymerase chain reaction for the etiological diagnosis of infectious endophthalmitis. J Postgrad Med. 2006;52(3):179-82.

12. Lohmann CP, Heeb M, Linde HJ, Gabel VP, Reischl $U$. Diagnosis of infectious endophthalmitis after cataract surgery by polymerase chain reaction. J Cataract Refract Surg. 1998;24(6):821-6.

13. Therese $K L$, Anand $A R$, Madhavan $H N$. Polymerase chain reaction in the diagnosis of bacterial endophthalmitis. $\mathrm{Br}$ J Ophthalmol. 1998;82(9):1078-82.

14. Chiquet $C$, Lina $G$, Benito $Y$, Cornut $P L$, Etienne J, Romanet JP, et al. Polymerase chain reaction identification in aqueous humor of patients with postoperative endophthalmitis. J Cataract Refract Surg. 2007;33(4):635-41

15. Carroll NM, Jaeger EE, Choudhury S, Dunlop AA, Matheson MM, Adamson P, et 
al. Detection of and discrimination between gram-positive and gram-negative bacteria in intraocular samples by using nested PCR. J Clin Microbiol. 2000;38(5):1753-7.

16. Anand $A R$, Madhavan $H N$, Therese $K L$. Use of polymerase chain reaction (PCR) and DNA probe hybridization to determine the Gram reaction of the infecting bacterium in the intraocular fluids of patients with endophthalmitis. J Infect. 2000;41(3):2216.

17. Knox CM, Cevallos V, Margolis TP, Dean D. Identification of bacterial pathogens in patients with endophthalmitis by $16 \mathrm{~S}$ ribosomal DNA typing. Am J Ophthalmol. $1999 ; 128(4): 511-2$.

18. Klein D. Quantification using real-time PCR technology: applications and limitations. Trends Mol Med. 2002;8(6):257-260.

19. Winn(h) W, Allen S, Janda W, Koneman E, Procop G, Schreckenberger P. Diagnóstico Microbiológico. Texto y Atlas a color. Editorial Panamericana. 6ta edición, 2006.

20. Fariña $N$, Carpinelli $L$, Samudio $M$, Guillén $\mathrm{R}$, Laspina F, Sanabria R, Abente et al. Staphylococcus coagulasa-negativa clínicamente significativos: Especies más frecuentes y factores de virulencia. Revista chilena de infectología, 2013; 30(5), 4808.

21. Clinical and Laboratory Standards Institute. Performance standards for antimicrobial susceptibility testing; twenty fifth Informational supplement and approved standard document M100-S25. Wayne, PA: CLSI; 2015.

22. Bispo PJM, Melo GB, d'Azevedo PA, HöflingLima $A L, Y u$ MCZ, Pignatari AC. Endoftalmites bacterianas com culturas positivas: uma revisão de 6 años. Arq Bras Oftalmolol. 2008;71(5):617-22.
23. Lohmann $\mathrm{CP}$, Linde $\mathrm{HJ}$, Reischl U. Improved detection of microorganisms by polymerase chain reaction in delayed endophthalmitis after cataract surgery. Ophthalmology. 2000;107(6):1047-51; discussion 1051-2.

24. Okhravi $N$, Adamson $P$, Matheson MM, Towler HM, Lightman S. PCR-RFLP mediated detection and speciation of bacterial species causing endophthalmitis. Invest Ophthalmol Vis Sci. 2000;41(6):1438-47.

25. Chiquet $\mathrm{C}$, Cornut $\mathrm{PL}$, Benito $\mathrm{Y}$, Thuret $\mathrm{G}$, Maurin M, Lafontaine PO, et al. Eubacterial PCR for bacterial detection and identification in 100 acute postcataract surgery endophthalmitis. Invest Ophthalmol Vis Sci. 2008; 49(5):1971-8.

26. Speers, DJ. Clinical Applications of Molecular Biology for Infectious Diseases. Clin. Biochem. Rev. 2006;27(1), 39-51.

27. Weisburg WG, Barnes SM, Pelletier DA. 16S ribosomal DNA amplification for phylogenetic study. J Bacteriol 1991;173:697-703.

28. Chen. $K$, Neimark $H$, Rumore $P$, Steinman CR. Broad range DNA probes for detecting and amplifying eubacterial nucleic acids. FEMS Microbiol Lett 1989; 48(1):19-24

29. Bispo PJ, Barreto de Melo G, Hofling-Lima AL,Campos Pignatari. Detection and Gram Discrimination of Bacterial Pathogens from Aqueous and Vitreous Humor Using RealTime PCR Assays. Invest Ophthalmol Vis Sci. 2011;52:873-81.

30. Ecker DJ, Drader JJ, Gutierrez J, Gutierrez A, Hannis JC, Schink A, et al. The Ibis T5000 universal biosensor: an automated platform for pathogen identification and strain typing. JALA-Journal of the Association for Laboratory Automation. 2006;11(6):341-51. 